\title{
Condenados a morrer
}

\section{Milena Geisa dos Santos Martins}

Mestra e Bacharel em Ciências Sociais pela Universidade Federal Rural do Rio de Janeiro (UFRRJ).

E-mail: milenamartins18@gmail.com

Não ter...

Não ter amor, sinceridade,

Perspectiva de futuro...

Não ter estudo, comida

Dormir no chão duro...

Não ter sonhos, planos,

Sobreviver de enganos...

Não ter vida digna, identidade,

Amadurecer sem saber quem se é de verdade.

Não ter saúde, educação...

Ser reconhecido pela sociedade como maldição.

"Sementes do mal",

É uma das classificações que lhes são atribuídas

Por aqueles que têm o que comer.

Da fértil terra periférica, subalterna e explorada;

Nascem batizados pelo sangue que escorre pelas ladeiras,

Periodicamente,

Amalgamado com a lama que jorra das encostas

Em temporadas de altos índices pluviométricos. 
Crescem e vivem em terra de ninguém.

Até que se cumpra o único destino possível,

E comecem a compor o pó dos execrados sociais

Em rasas covas

Que nunca se esvaziam...

Por ação do homem ou da fome,

Já nasceram condenados a morrer. 